\title{
Transition dairy cow health is associated with first postpartum ovulation risk, metabolic status, milk production, rumination, and physical activity*
}

\author{
Jeffrey S. Stevenson, $†$ ๑๐ Sevastian Banuelos, and Luís G. D. Mendonça ${ }^{\circledR}$ \\ Department of Animal Sciences and Industry, Kansas State University, Manhattan 66506-0201
}

\begin{abstract}
Our objective was to determine the association of health status during the first $60 \mathrm{~d}$ in milk (DIM) and first postpartum ovulation risk, physical activities recorded by an activity monitor, and metabolic and milk measures in Holstein cows. Late-gestation heifers and close-up dry cows in 1 herd fitted with CowManager SensOors (Agis, Harmelen, the Netherlands) were enrolled in the study $3 \mathrm{wk}$ before expected parturition to assess ear skin temperature and daily rumination, eating, inactivity, and activity times. Blood samples were collected at calving (d 0), and on d 3, 7, and 14 to assess concentrations of free fatty acids, $\beta$-hydroxybutyrate (BHB), calcium, glucose, and haptoglobin. In addition, weekly measures were conducted for body condition, body weight, and progesterone through $63 \pm 3$ DIM when ovulation was synchronized $(\mathrm{GnRH}-1-7$ $\mathrm{d}-\mathrm{PGF}_{2 \alpha}-24 \mathrm{~h}-\mathrm{PGF}_{2 \alpha}-32 \mathrm{~h}-\mathrm{GnRH}-2-16$ $\mathrm{h}-$ artificial insemination). Disease diagnosed in 68 of 160 cows (42.5\%) was distributed equally between primiparous $(48.5 \%)$ and multiparous $(51.5 \%)$ cows. Cows were classified as diseased when any case of metritis, digestive disorders, ketosis, hypocalcemia, calving problems, mastitis, or lameness occurred during the first 60 DIM. Odds of early ovulation by median postpartum d 33 was 1.92 times greater in healthy than diseased cows. Incidence of individual diseases included metritis (18.8\%), digestive disorders (17.5\%), ketosis (BHB >10 mg/dL; 11.9\%), hypocalcemia ( $\mathrm{Ca}<2.2$ $\mathrm{mmol} / \mathrm{L} ; 10.6 \%)$, calving problems $(6.3 \%)$, mastitis (3.1\%), and lameness (3.1\%). Odds of early ovulation were $2.48,2.65$, and 5.72 times greater in healthy cows compared with cows diagnosed with metritis, digestive disorders, or ketosis, respectively. Diseased compared with healthy cows had greater concentrations of free

Received April 2, 2020.

Accepted June 4, 2020.

*Contribution number 20-243-J from the Kansas Agricultural Experiment Station, Manhattan.

$\dagger$ Corresponding author: jss@ksu.edu
\end{abstract}

fatty acids, BHB, haptoglobin, greater rectal temperature, and lesser concentration of serum calcium on d 0 , 3,7 , and 14 than healthy cows. Plasma glucose was not affected by health status, but was lesser in concentration on d 3, 7, and 14 compared with day of calving. Weekly (calving through 9 wk) body condition scores tended to be and weekly body weights were greater in healthy compared with diseased cows. Activity measures differed by health status during prepartum (d -14 through -1) and postpartum (d 0 through 20) periods except for eating time. Healthy cows spent less time being inactive during both periods compared with diseased cows and had greater postpartum rumination times than diseased cows. Mean daily milk yield during the first 14 wk in milk was greater in healthy than diseased cows by $2.1 \pm 0.8 \mathrm{~kg}$. We conclude that disease negatively affects early postpartum ovulation risk and is associated with measurable changes in periparturient physical activity and postpartum metabolic profiles.

Key words: activity monitoring, dairy cow, postpartum ovulation, transition health

\section{INTRODUCTION}

Postpartum disease and disorders in dairy cows have a negative effect on culling, lactation, and reproductive performance (Carvalho et al., 2019). Approximately one-third of dairy cows have at least 1 clinical disease (metritis, mastitis, digestive problem, respiratory problem, or lameness) during the first 3 wk of lactation (Ribeiro and Carvalho, 2017). All reproductive disorders either directly or indirectly reduce reproductive performance as well as milk yields (Stevenson and Call, 1989). Transition from pregnancy (no lactation) to lactation (not pregnant) presents the greatest risk for culling and death for a dairy cow, which is exacerbated in cows having increased days open during the previous lactation (Pinedo and De Vries, 2010). Failure to adapt to metabolic demands of milk production increases the risk for periparturient diseases and hinders subsequent reproductive success and milk yield. Calving-related disorders and diseases that affect the reproductive tract are major contributors to poor fertility. In 2013, 
the most common clinical diseases in cows reported by dairy producers were mastitis $(24.8 \%)$, any degree of lameness (16.8\%), infertility (8.2\%), and metritis (6.9\%; NAHMS, 2014). Cows that have one of the aforementioned disorders were 50 to $63 \%$ less likely to resume estrous cycles by the end of the voluntary waiting period, and were 25 to $38 \%$ less likely to become pregnant after the first AI breeding compared with healthy cows (NAHMS, 2014).

Identifying cows that are at greater risk for disease is an essential part of transition management (Bicalho et al., 2017). Prevalence of periparturient disease has been studied in grazing (Ribeiro et al., 2013) and confined dairy operations (Stevenson and Call, 1988; Santos et al., 2009). Metabolic profiling of blood metabolites such as nonesterified fatty acids (NEFA; Drackley, 1999), BHB (Drackley, 1999), calcium (Martinez et al., 2016; Venjakob et al., 2018), glucose (Dubuc and Buczinski, 2018), and other enzymes (Mohtashamipour et al., 2020) or acute-phase proteins (Barragan et al., 2019) has been conducted to identify cows at risk and to predict reproductive success (Ospina et al., 2010; Ribeiro et al., 2013; Carvalho et al., 2019).

Blood sampling can be time consuming, expensive, and for most farms impractical because of herd size and cost. New technologies allow management of cows using limited labor user-friendly technology that assesses various activities such as rumination, resting, and eating behaviors in addition to monitoring behavioral activities associated with estrus. Management activities and facilities can either limit or facilitate vital cow activities such as eating, drinking, lying, resting, ruminating, socializing with pen mates, and standing behavior associated with estrus (Grant and Albright, 2000). These essential activities make up a daily "time budget" for a productive dairy cow housed in a freestall environment: approximately 3 to $5 \mathrm{~h}$ eating, 12 to $14 \mathrm{~h}$ lying or resting, 2 to $3 \mathrm{~h}$ of social interactions, 7 to 10 $\mathrm{h}$ ruminating, 30 min drinking, and 2.5 to $3.5 \mathrm{~h}$ outside the home pen (i.e., milking or travel time). Cows have a definite requirement for resting (lying down) that may compromise feeding behavior (Grant and Albright, 2000).

Behavior can predict and identify ill health in animals (Weary et al., 2009). Activity monitors can provide valuable information about these important behaviors that are correlated with economic traits associated with health, milk yield, and estrus detection. Activity-monitored measures correlate with visual observations and provide accurate information for use in management of dairy cattle (Borchers et al., 2016). Relationships have been determined between rumination time and incidences of various diseases or disorders (Liboreiro et al., 2015). Others have examined associations of rumination and activity with specific diseases such as metabolic and digestive disorders (Stangaferro et al., 2016a), mastitis (Stangaferro et al., 2016b), and metritis (Stangaferro et al., 2016c). Furthermore, during the transition period, lying and standing times differed among parity groups and their response to postpartum health events (Piñeiro et al., 2019).

Relationships of health and metabolic markers, in addition to measures of resting, eating, rumination, and activity derived from CowManager SensOor (Agis, Harmelen, the Netherlands) ear tags, have not been studied to determine their relationships to subsequent ovulation, estrus, and health status. Our objective was to characterize associations between periparturient disease and multiple physiological indicators of cow status, which included (1) metabolic status [free fatty acids (FFA), BHB, glucose, haptoglobin, and calcium]; and (2) physical and performance traits (BCS, BW, milk yield, eating, rumination time, activity time, and postpartum interval to first ovulation and estrus) in transition dairy cows.

\section{MATERIALS AND METHODS}

Close-up dry Holstein cows and late-gestation heifers at the Kansas State University Dairy Teaching and Research Center were enrolled beginning 3 wk before expected calving date. Of 86 heifers and 82 cows that calved between December 2017 and August 2018, 8 cows did not complete the study because of chronic disorders (e.g., debilitating lameness and mastitis) that occurred early in the study. At the beginning of the study, the 365-d rolling herd average was $14,205 \mathrm{~kg}$ of milk (518 kg of fat and $415 \mathrm{~kg}$ of protein). The experiment was conducted under the Kansas State University Institutional Animal Care and Use Committee application \#3219.

Cows and heifers (115 of the 160 cows used in the study) were fitted with SensOor ear tags (Agis CowManager) during midgestation before study enrollment to monitor measures of ear skin temperature, eating, rumination, and inactive times, in addition to daily measures of activity and high activity. Activity measures all movement that is not eating, resting (no activity), or rumination. High activity is reflective of estrual activity. Total activity is the sum of activity and high activity.

Multiple concurrent events were measured, but the activity measures are parsed into individual minutes of data capture. The activity or event that occupies the majority of each minute is recorded as one single event per minute. Data captured from the ear tags were stored in the cloud and daily downloaded into Excel (Microsoft Corp., Redmond, WA) spreadsheets. Hourly 
data were averaged to produce a daily mean for each activity captured by the ear tag.

Daily temperature and relative humidity data were obtained from the Kansas State University Weather Library for the duration of data collection (December 2017 through August 2018). The official weather station is located at $39.2^{\circ} \mathrm{N}$ latitude, $96.6^{\circ} \mathrm{W}$ longitude, and at elevation of $336.6 \mathrm{~m}$ on the Kansas State University Agronomy Farm $<2 \mathrm{~km}$ south of where experimental cows were housed. Heat index (temperature-humidity index, THI) was calculated using a standard formula (NOAA, 1976).

Close-up dry cows and late-gestation heifers were housed in an open-front, straw-bedded maternity barn until parturition, half of which was covered by a roof. The maternity barn was equipped with evaporative pads and fans (operational except for $2 \mathrm{~h}$ from 0100 to $0300 \mathrm{~h}$ each night) along the north side of the barn that were functional during days when the temperature exceeded $22^{\circ} \mathrm{C}$. After parturition, cows were moved to open lot freestall barns bedded with sand, and milked thrice daily. Freestalls were covered by a roof with overhead fans and sprinklers installed over the feed lane, which operated for $30 \mathrm{~s}$ every $10 \mathrm{~min}$ when the temperature exceeded $22^{\circ} \mathrm{C}$. Routine daily monitoring of fresh cows by herd personnel included assessing body temperature and urine ketones during the first 7 to 10 $\mathrm{d}$ after calving. In addition, health disorders (i.e., calving problems such as dystocia and retained placenta, mastitis, digestion, and lameness) were recorded in the on-farm management software (PCDART, Dairy Records Management Systems, Raleigh, NC).

\section{Metabolic and Body Measures}

In addition to routine postpartum cow monitoring by herd personnel, the following measures and diagnoses were made by the authors (Figure 1). Body condition scores $(1=$ thin and $5=$ obese; Edmonson et al., 1989) and BW were assessed beginning at calving and weekly until $63 \pm 3$ DIM. Rectal temperature was assessed by using a digital thermometer (GLA Agricultural Electronics, San Luis Obispo, CA) and blood samples were collected by puncture of the coccygeal vein or artery on postpartum d 0 (calving), 3, 7, and 14 to assess serum concentrations of FFA, BHB, calcium, haptoglobin, and plasma glucose (Figure 1). Blood was collected into evacuated tubes, placed on ice, and transported to the laboratory. Samples were centrifuged at $1,000 \times g$ for $15 \mathrm{~min}$ at $4^{\circ} \mathrm{C}$ between 8 and $24 \mathrm{~h}$ after collection to harvest serum. To assess glucose, blood samples were collected into evacuated 7 -mL tubes containing additives (75 USP units sodium heparin) for plasma collection, mixed well by hand, placed on ice, and centrifuged as described by $2 \mathrm{~h}$ after collection.

Plasma and serum samples were frozen at $-20^{\circ} \mathrm{C}$ and later analyzed for concentrations of FFA (NEFA-C kit; Wako Diagnostics Inc., Richmond, VA), BHB (kit \#H7587-58; Pointe Scientific Inc., Canton, MI), and glucose (kit \#439-90901, Wako Chemicals USA Inc.) by enzymatic methodology. Interassay coefficients of variation $(\mathbf{C V})$ averaged $3.28,3.59$, and $2.90 \%$, respectively. Concentrations of total calcium were determined using an atomic absorption spectrophotometer (AAnalyst 200, Perkin-Elmer Inc., Waltham, MA; Martinez et

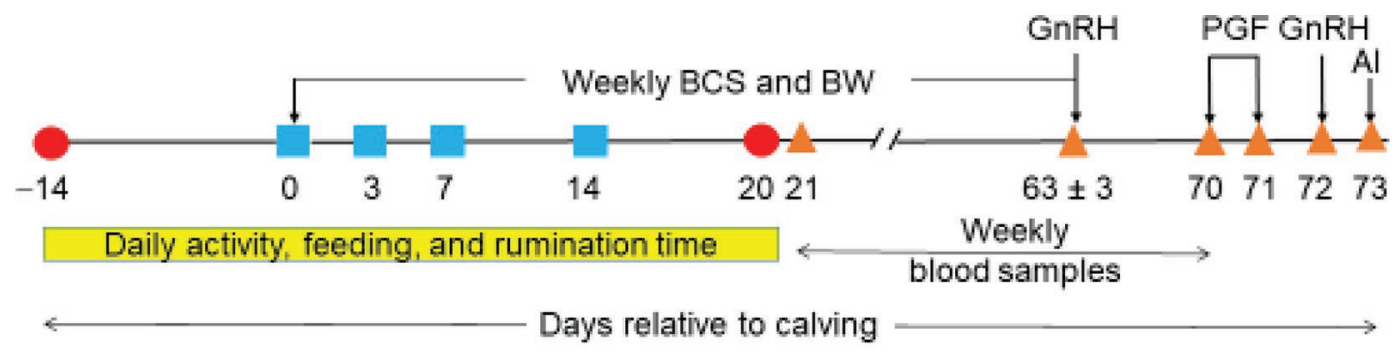

FFA, BHB, Glucose, Ca, Haptoglobin, and body temperature

Activity monitoring ( -14 to +20 days)

Progesterone

Figure 1. Experimental scheme describing sample collection and experimental activities. Activity monitoring (eating, rumination, ear skin temperature, and inactive and active periods) via SensOor (Agis, Harmelen, the Netherlands) ear tags was recorded from -14 to $+20 \mathrm{~d}$ from calving $(\mathrm{d} 0=$ calving $)$. Rectal temperature and blood samples were collected on d $0,3,7$, and 14 to measure serum concentrations of free fatty acids (FFA), BHB, haptoglobin, and Ca, and plasma concentrations of glucose. Cows were classified as diseased when any case of metritis, digestive disorders, ketosis, hypocalcemia, calving problems, mastitis, or lameness occurred during the first 60 DIM. Body condition scores and BW were assessed on d 0 and weekly until $63 \pm 3$ DIM. Weekly blood samples were collected beginning at d $21 \pm 3$ to d $63 \pm 3$ for later assessment of serum concentrations of progesterone. Ovulation was synchronized by administering GnRH and PGF ${ }_{2 \alpha}$ beginning at $63 \pm 3$ DIM. Furthermore, blood samples were collected before treatment injections of $\mathrm{GnRH}$ and PGF to evaluate progesterone concentration. 
al., 2016). Interassay CV averaged 2.34\%. Haptoglobin was measured as described by Makimura and Suzuki (1982) with interassay CV averaging $8 \%$.

\section{Reproductive Traits}

Blood samples were collected weekly beginning on d $21 \pm 3$ until d $63 \pm 3$ to determine the onset of luteal function and before ovulation synchronization injections of $\mathrm{GnRH}$ and $\mathrm{PGF}_{2 \alpha}$ for later assessment of progesterone concentration (Figure 1). Concentrations of progesterone in blood serum were measured by direct quantitative (nonextracted) RIA using ImmuChem Double Antibody progesterone ${ }^{125}$ I kits (MP Biomedicals LLC, Solon, OH) previously validated for bovine serum (Hill et al., 2016). Intra- and interassay coefficients of variation for a low $(0.26 \pm 0.01 \mathrm{ng} / \mathrm{mL})$ were 5.2 and $16.6 \%$ and for a luteal marginal $(1.22 \pm$ $0.1 \mathrm{ng} / \mathrm{mL}$ ) concentration pool were 6.4 and $16.1 \%$, respectively. Calculated assay sensitivity averaged $0.15 \pm$ $0.5 \mathrm{ng} / \mathrm{mL}$, and progesterone standard concentrations in the assay were $0.05,0.1,0.2,0.5,2.0,5.0,10.0$, and $25.0 \mathrm{ng} / \mathrm{mL}$.

Day of ovulation was defined to occur midway between the last weekly sample when progesterone $<1$ $\mathrm{ng} / \mathrm{mL}$ and the next weekly sample when progesterone $>1 \mathrm{ng} / \mathrm{mL}$. Estrual alerts generated by the SensOor ear tags produced dates, duration (h), and intensity (arbitrary units) of estrus during the postpartum period until first insemination. Beginning at $63 \pm 3$ DIM, cows were enrolled in a modified ovulation synchronization program [GnRH-1 (2 mL of Factrel, Zoetis Inc., Kalamazoo, MI) $-7 \mathrm{~d}-\mathrm{PGF}_{2 \alpha}$ (2 $\mathrm{mL}$ of Lutalyse HighCon, Zoetis Inc.) $-24 \mathrm{~h}-\mathrm{PGF}_{2 \alpha}-32 \mathrm{~h}-\mathrm{GnRH}-2-16 \mathrm{~h}$ - AI; Figure 1]. Blood samples also were collected at 63, 70 , and $73 \pm 3$ DIM to assess progesterone responses to Ovsynch [i.e., luteolysis (progesterone $\leq 0.32 \mathrm{ng} / \mathrm{mL}$ at AI)]. Ovaries were scanned transrectally by ultrasonography $(7.5 \mathrm{MHz}$ linear-array transducer, Ibex EVO, E.I. Medical Imaging, Loveland, CO) at 63, 70, 73, and $77 \pm 3$ DIM to determine follicle diameters (average of vertical and horizontal diameter measures using electronic calipers), number of luteal structures, and ovulatory response (disappearance of mapped follicle) to both GnRH treatments (GnRH-1 and GnRH-2).

\section{Definitions and Assessment of Disease}

The following postpartum diseases were diagnosed or assessed during the first 60 DIM: metritis, digestive disorders, ketosis, hypocalcemia, calving problems, mastitis, or lameness. Two health statuses were detected: diseased or healthy. Cows $(\mathrm{n}=68)$ were defined as diseased when any case of metritis, digestive disorders, ketosis, hypocalcemia, calving problems, mastitis, or lameness was diagnosed. The remaining cows $(\mathrm{n}=92)$ were defined to be healthy.

Metritis was diagnosed when evidence of brown watery exudate detected by palpation per rectum at d 3 , 7 , and 14. Metritis was characterized by the presence of fever and a red/brown watery fetid uterine discharge (LeBlanc, 2010). Standard treatment included ceftiofur hydrochloride (Zoetis Inc.) for 3 consecutive days.

Digestive disorders were diagnosed during the first 60 DIM when any cow had a displaced abomasum (history and clinical signs in combination with auscultation findings with a distinct ping identified by using a stethoscope), diarrhea, off feed, or treatment with antidiarrheal medications (Bismu-Kote, Vedco Inc., St. Joseph, MO).

Ketosis was diagnosed when large or moderate ketones were detected in urine by using TRUEplus ketone test strips (Trividia Health, Fort Lauderdale, FL) during the first $10 \mathrm{~d}$ postpartum, followed by treatment with ketogel, propylene glycol, or dextrose, or when BHB concentration exceeded a threshold of $10 \mathrm{mg} / \mathrm{dL}$ in any of 3 of 4 samples collected on postpartum d 0,3 , 7, or 14 (Ospina et al., 2010; Ribeiro et al., 2013).

Subclinical hypocalcemia was diagnosed retrospectively when serum calcium was $<2.20 \mathrm{mmol} / \mathrm{L}$ in any of 3 of 4 samples collected on postpartum d $0,3,7$, or 14 (Ribeiro et al., 2013; Dubuc and Buczinski, 2018; Venjakob et al., 2018). Only 3 cows diagnosed with subclinical hypocalcemia were later diagnosed and treated for clinical milk fever. Calving problems included any cow with twins or a calving difficulty score of 3 or greater ( $1=$ no problems; $5=$ extreme difficulty), or retained placenta (failure to expel fetal membranes by $24 \mathrm{~h}$ after calving). Cows were not treated specifically for either calving difficulty or retained placenta. Clinical mastitis was assessed when abnormal milk was detected by milking technicians during the first 60 DIM postpartum and cows were treated with antibiotic. Lameness until 60 DIM included any cow with joint swelling (hock, pastern, or stifle), hoof ulcers, and obvious limping. Treatments included hoof trimming, applying blocks to ulcerated hooves, or both.

To assess seasonal effects, calving months were categorized into 2 seasons. Winter-spring calvings (December through April) were compared with summer calvings (May through August). For winter-spring calvings, the THI ranged from 12.8 to 67.6 , with an average of 42.0. In contrast, for summer calvings, the THI ranged from 60.8 to 82.3 , with an average of 73.6 . During 79 of the $90 \mathrm{~d}$ of the summer period, the THI exceeded 68 at which heat stress effects are known to reduce milk yield (Habeeb et al., 2018). 


\section{Statistical Analyses}

Cow was the sampling unit and treated as a random effect in all models. All analyses were performed by using SAS 9.4 software (SAS Institute Inc., Cary, NC). Rectal temperature, and concentrations of FFA, BHB, calcium, haptoglobin, and glucose assessed on d 0,3 , 7 , and 14 were analyzed by using a mixed model procedure (MIXED procedure) to account for correlated repeated measures. The model consisted of the fixed effects of health status (healthy vs. diseased), parity (primiparous vs. multiparous), day, interaction of day with health status, interaction of health status and parity, and season. Day was the REPEATED term in the model. Health status was tested by the cow within health status variance (split-plot error), whereas all other model variables were tested by the residual error (whole-plot error). The covariance structure varied with each MIXED model. The tested covariance structures included autoregressive with and without heterogeneity, compound symmetry with and without heterogeneity, and Toeplitz. The final model chosen for each variable included the covariance structure that produced the smallest Akaike's information criteria.

Prepartum ( $\mathrm{d}-14$ through -1$)$ and postpartum (d 0 through 20) activity measures were analyzed similarly but in separate prepartum or postpartum models. All repeat-measure activity measures (i.e., daily times of eating, rumination, ear skin temperature, inactivity, and total activity from -14 through $+20 \mathrm{~d}$ postcalving) were analyzed as described previously using the same repeat-measure MIXED model and appropriate covariance structure determinations. Weekly BW and BCS were analyzed as described using the same repeatmeasure MIXED model but substituting week for day.

Non-repeat-measure traits including milk yield data, milk components, SCC, and other measures (days to first ovulation and first estrus, duration and intensity of estrus, ovarian follicle diameters, BW and BCS at calving and at $\mathrm{AI}$ ) were analyzed by ANOVA (procedure GLM). The model consisted of health status, parity, their interaction, and season of calving. Milk yield DHI test-day data $(3.5 \%$ FCM and ECM, fat and protein yield, and percentages) included 1 test-day between 51 and 94 DIM $( \pm 20 \mathrm{~d}$ of $\mathrm{AI})$ and average daily milk during the first $14 \mathrm{wk}$ of lactation (including 150- and 305-d ECM) using the same statistical model.

Binomial data were analyzed by logistic regression (procedure GLIMMIX) by using the model of health status, parity, their interaction, and season of calving. Options used in the model statement included LINK $=$ LOGIT, DIST $=$ BINOMIAL, and the least squares means option of ILINK and DIFF.
All mean comparisons of health status (healthy vs. diseased), parity (primiparous vs. multiparous), and season (winter-spring vs. summer) were by $F$-tests. When interactions occurred in which more than 2 means were compared, means were separated by the least significant difference test in SAS. In all cases, statistical significance of effects was set as $P<0.05$, with tendencies as $0.05<P \leq 0.10$.

\section{RESULTS}

\section{Disease Incidence}

Incidence of at least one disease or disorder was $42.5 \%(\mathrm{n}=68)$. Of the 68 cows diagnosed with disease, $48.5 \%$ had 1 disease, $35.5 \%$ had 2 different diseases, and $16.2 \%$ had 3 diseases diagnosed. Mean and median DIM for timing of individual disease diagnoses are in Table 1. Disease incidence ranged from $3.1 \%$ for lameness or mastitis to $18.8 \%$ for metritis. Disease diagnoses were distributed equally between primiparous (48.5\%) and multiparous $(51.5 \%)$ cows. Only ketosis incidence was greater $(P=0.02)$ in multiparous than primiparous cows (18.0 vs. $6.1 \%$, respectively).

Health status was consistent with metabolite measures assessed in samples collected on d $0,3,7$, and 14 (Figure 2). Healthy compared with diseased cows had lesser $(P<0.001)$ serum concentrations of FFA, $\mathrm{BHB}$, and haptoglobin, whereas serum calcium was greater $(P<0.001)$ in healthy cows. Primiparous cows had lesser $(P<0.01)$ concentrations of FFA than multiparous cows $(0.47 \pm 0.02$ vs. $0.56 \pm 0.02 \mathrm{mEq} / \mathrm{L}$, respectively), whereas no seasonal effect $(P=0.14)$ was detected for serum concentrations of FFA. No health status by parity interactions were detected for any of the metabolic measures.

Concentrations of BHB were greater $(P<0.01)$ in multiparous than primiparous cows $(8.3 \pm 0.2$ vs. 7.1 $\pm 0.2 \mathrm{mg} / \mathrm{dL}$, respectively) and greater $(P<0.01)$ for cows calving during winter-spring months compared with summer $(8.2 \pm 0.2$ vs. $7.2 \pm 0.2 \mathrm{mg} / \mathrm{dL}$, respectively; Figure 2). Concentrations of haptoglobin were greater $(P=0.03)$ in primiparous than multiparous cows (12.1 \pm 0.4 vs. $11.1 \pm 0.4$ units, respectively) and for cows calving during summer versus winter-spring months (12.5 \pm 0.4 vs. $10.7 \pm 0.4$ units, respectively). Furthermore, neither parity $(P=0.35)$ nor season of calving $(P=0.43)$ affected concentrations of calcium or haptoglobin.

Rectal temperatures were greater $(P<0.01)$ on $\mathrm{d}$ 3,7 , and 14 compared with those at calving (Figure 3 ; upper panel). Diseased cows had greater $(P<0.01)$ rectal temperatures than healthy cows on $\mathrm{d} 3,7$, and 
Table 1. Disease incidence and risk of early ovulation

\begin{tabular}{|c|c|c|c|c|c|c|}
\hline \multirow[b]{2}{*}{ Item } & \multirow{2}{*}{$\begin{array}{c}\text { Incidence } \\
(\%)\end{array}$} & \multirow[b]{2}{*}{$\begin{array}{l}\text { Mean (median) } \\
\text { days to diagnosis }\end{array}$} & \multirow{2}{*}{$\begin{array}{l}\text { Early ovulation } \\
\operatorname{risk}^{1}(\%)\end{array}$} & \multicolumn{3}{|c|}{ Univariate analysis } \\
\hline & & & & $\mathrm{OR}^{2}$ & $95 \% \mathrm{CI}$ & $P$-value \\
\hline Healthy $(\mathrm{n}=92)$ & 57.5 & - & 54.4 & Referent & & \\
\hline \multicolumn{7}{|l|}{ Type of disorder } \\
\hline Metritis ${ }^{4}$ & 18.8 & $3.0(3)$ & 30.0 & 2.48 & $1.06-5.82$ & 0.03 \\
\hline Digestive $^{5}$ & 17.5 & $8.1(7)$ & 28.6 & 2.65 & $1.09-6.46$ & 0.03 \\
\hline Mastitis $^{9}$ & 3.1 & $34.3(46)$ & 80.0 & 0.22 & $0.02-1.98$ & 0.14 \\
\hline Lameness $^{10}$ & 3.1 & $38.1(28.5)$ & 60.0 & 0.59 & $0.10-3.25$ & 0.57 \\
\hline
\end{tabular}

${ }^{1}$ Early ovulating cows had their first increase in weekly progesterone $\geq 1 \mathrm{ng} / \mathrm{mL}$ or ultrasound-detected corpus luteum by 33 DIM (median).

${ }^{2}$ Odds ratio.

${ }^{3}$ Any case of diagnosed metritis, digestive disorders, ketosis, hypocalcemia, calving problems, mastitis, or lameness during the first 60 DIM.

${ }^{4}$ Metritis $=$ evidence of brown watery exudate detected by transrectal palpation at d $0,3,7$, and 14 postpartum.

${ }^{5}$ Disorders were diagnosed during the first 60 DIM including displaced abomasum, diarrhea, or off feed.

${ }^{6}$ Cows diagnosed with large or moderate ketones, followed by treatment with ketogel, propylene glycol, or dextrose, or diagnosed when BHB concentrations exceeded $10 \mathrm{mg} / \mathrm{dL}$ in 3 of 4 samples collected on postpartum d $0,3,7$, or 14 .

${ }^{7}$ Concentrations of calcium $<2.20 \mathrm{mmol} / \mathrm{L}$ in 3 of 4 samples collected on postpartum d 0,3 , 7, or 14 (included 3 treated cases of milk fever).

${ }^{8}$ Twins, retained fetal membranes, or a calving difficulty score of 3 or greater $(1=$ no problems; $5=$ extreme difficulty $)$.

${ }^{9}$ Any case of antibiotic-treated abnormal milk occurring during the first $60 \mathrm{~d}$ postpartum.

${ }^{10}$ Swelling of joints, hoof ulcers, and limping during the first 60 DIM.

14 (health status by day interaction), but not on the day of calving. Rectal temperatures tended $(P=0.09)$ to be greater for cows calving during summer than winter-spring months $\left(39.0 \pm 0.03\right.$ vs. $\left.38.9 \pm 0.03^{\circ} \mathrm{C}\right)$, respectively, but no parity differences $(P=0.57)$ were detected. Health status did not affect plasma glucose on d $0,3,7$, or 14 , but overall concentrations were less
$(P<0.01)$ on $\mathrm{d} 3,7$, and 14 compared with that at calving (Figure 3; lower panel). Plasma glucose also was less $(P<0.01)$ in multiparous than primiparous cows $(57.3 \pm 0.8$ vs. $66.6 \pm 0.7 \mathrm{mg} / \mathrm{dL}$, respectively), and tended $(P=0.08)$ to be less for cows calving during winter-spring than summer months $(61.2 \pm 0.7$ vs. $62.6 \pm 0.8 \mathrm{mg} / \mathrm{dL}$, respectively).
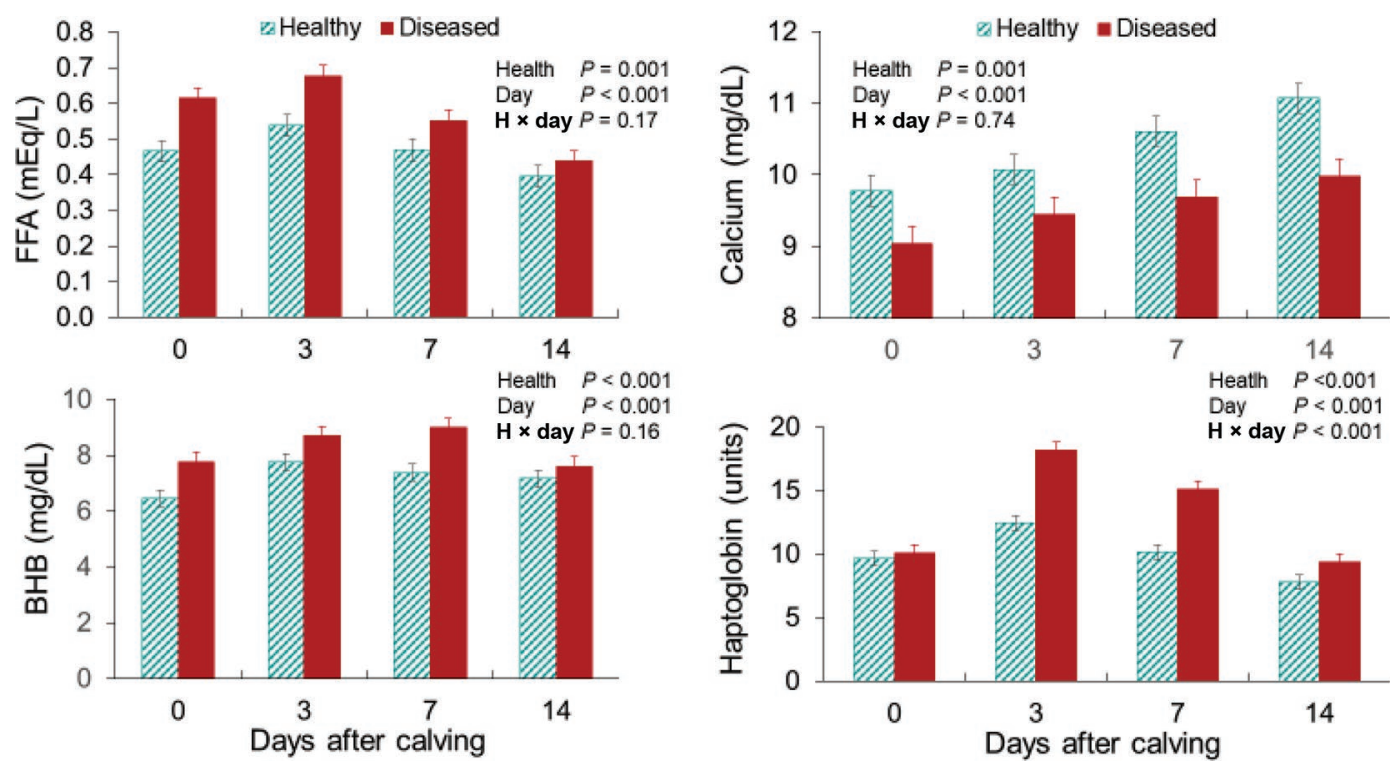

Figure 2. Least squares means $( \pm$ SEM) concentrations of serum free fatty acids (FFA), BHB, calcium, and haptoglobin on d $0,3,7$, and 14 after calving for healthy $(\mathrm{n}=92)$ and diseased $(\mathrm{n}=68)$ dairy cows. Diseased cows included any case of defined metritis, digestive disorders, ketosis, hypocalcemia, calving problems, mastitis, or lameness during the first 60 DIM. 

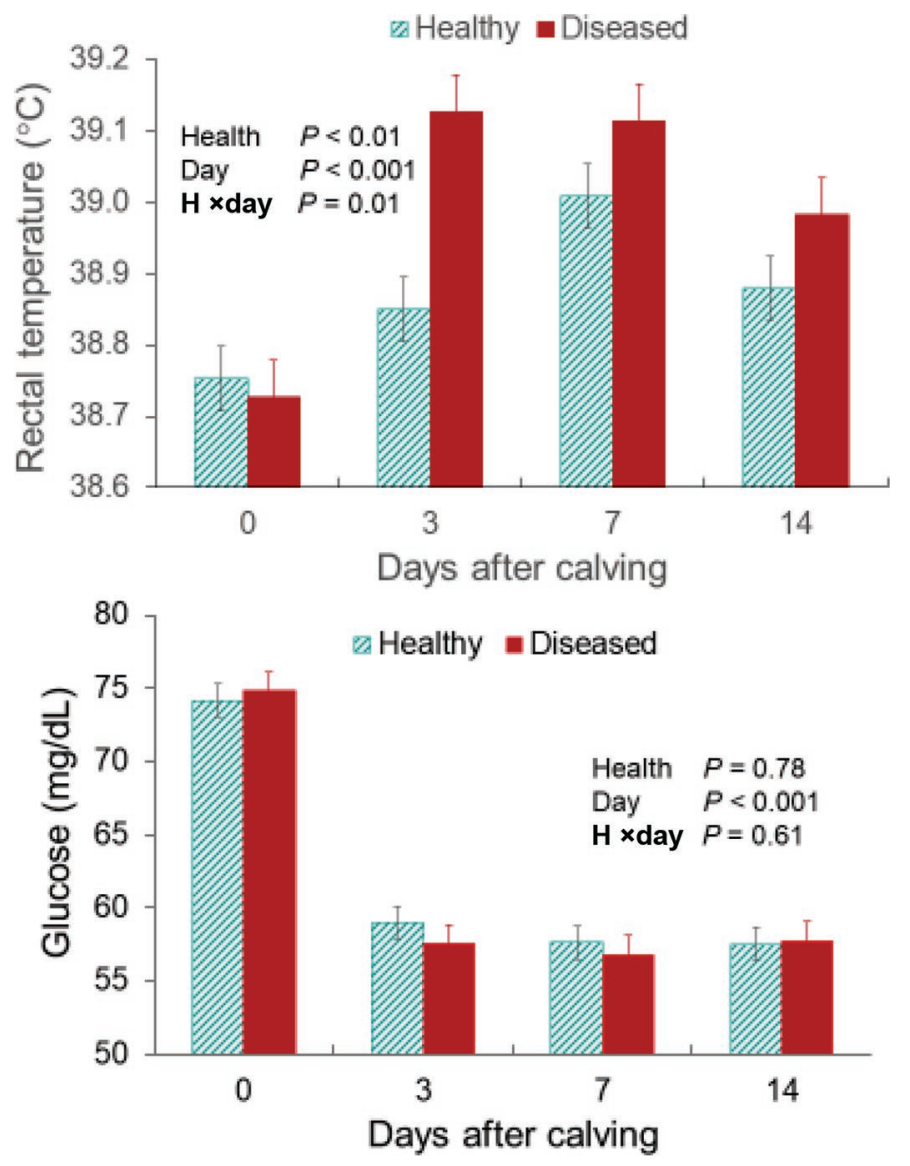

Figure 3. Least squares means $( \pm$ SEM) rectal temperatures (upper panel) and concentrations of plasma glucose (lower panel) and on d $0,3,7$, and 14 after calving for healthy $(\mathrm{n}=92)$ and diseased $(\mathrm{n}=$ 68) dairy cows. Diseased cows included any case of defined metritis, digestive disorders, ketosis, hypocalcemia, calving problems, mastitis, or lameness during the first 60 DIM.

Daily minimum, maximum, and average ear skin temperatures assessed on d $0,3,7$, and 14 were highly correlated $(P<0.001)$ with the daily minimum $(\mathrm{r}=$ $0.94)$, maximum $(\mathrm{r}=0.95)$, and average $(\mathrm{r}=0.96)$ environmental temperatures. In contrast, rectal temperatures assessed on those same days were correlated $(P<0.001)$ with daily minimum $(\mathrm{r}=0.21)$, maximum $(\mathrm{r}=0.23)$, and average $(\mathrm{r}=0.22)$ environmental temperatures, but at lesser magnitudes. The magnitudes of the correlations $(\mathrm{r}=0.22)$ between ear skin temperature and rectal temperature were in the same range as the correlations between rectal and environmental temperatures, indicating that the ear skin temperature was more closely related to environmental conditions than to body temperature.

Daily ear skin temperatures (data not shown) did not differ $(P=0.81)$ by health status during either the prepartum or postpartum periods because of large variation in days and cows. Ear skin temperatures dur- ing the first $20 \mathrm{~d}$ postpartum, however, increased $(P$ $<0.01$ ) by day in healthy cows from a nadir on $\mathrm{d} 1$ through 8 , at which time they leveled off, whereas temperature in diseased cows continued to increase through d 20 postpartum. Parity had no effect on ear skin temperatures either before or after calving. In contrast, ear skin temperature was predictably greater $(P<0.01)$ for cows calving during summer versus winter-spring months during both prepartum $(31.1 \pm 0.6$ vs. 22.9 $\pm 0.5^{\circ} \mathrm{C}$, respectively) and postpartum $(32.6 \pm 0.9$ vs. $23.9 \pm 0.7^{\circ} \mathrm{C}$, respectively) periods.

\section{Activity Measures}

Prepartum ( $\mathrm{d}-14$ through $\mathrm{d}-1)$ and postpartum (d 0 through d 20) daily averages for inactivity (resting), rumination, eating, and total activity are illustrated in Figure 4. Cows diagnosed with disease were less active (rested more) during the prepartum $(P=0.02)$ and postpartum $(P<0.001)$ periods than healthy cows (Figure 4; upper left panel), with the greatest difference between health statuses during the postpartum period. Inactive time peaked on $\mathrm{d} 1$ in healthy cows, and was lesser $(P<0.05)$ than diseased cows. Peak of inactive time in diseased cows was on $\mathrm{d} 2$. Inactive time was not affected by parity $(P>0.17)$, but an interaction was detected $(P=0.02)$ between health status and parity during the prepartum, but not during the postpartum period. Healthy and diseased primiparous cows had prepartum inactive times that did not differ $(409.4 \pm$ 10.9 vs. $413.5 \pm 12.2 \mathrm{~min} / \mathrm{d}$, respectively), whereas multiparous diseased cows were more $(P=0.02)$ inactive (rested more) prepartum than healthy multiparous cows $(451.3 \pm 12.3$ vs. $394.4 \pm 11.0 \mathrm{~min} / \mathrm{d}$, respectively). Daily inactivity was greater for cows calving during winter-spring than summer months during both the prepartum $(P<0.01 ; 443.3 \pm 7.7$ vs. $391.4 \pm 9.0$ $\mathrm{min} / \mathrm{d}$, respectively $)$ and postpartum $(P=0.06 ; 400.5$ \pm 10.1 vs. $374.7 \pm 11.4 \mathrm{~min} / \mathrm{d}$, respectively) periods.

Prepartum rumination times were unaffected by health status, but were greater $(P=0.05)$ in healthy than diseased cows after calving (Figure 4; upper right panel). Prepartum rumination slowly decreased and then abruptly by $90 \mathrm{~min} 24 \mathrm{~h}$ before parturition reaching a nadir by $24 \mathrm{~h}$ after calving. Thereafter, rumination in healthy cows increased rapidly to a peak on $\mathrm{d}$ 8 to 9 and leveled off, whereas the peak in rumination in diseased cows was delayed to d 15 before leveling off. Daily rumination was less $(P=0.04)$ during the prepartum period in gestating heifers (primiparous cows) than in multiparous cows $(395.2 \pm 9.0$ vs. 421.8 $\pm 9.3 \mathrm{~min} / \mathrm{d})$, whereas season had no effect $(P=0.25)$ on daily rumination. After calving, primiparous cows ruminated fewer $(P<0.01)$ minutes per day than older 

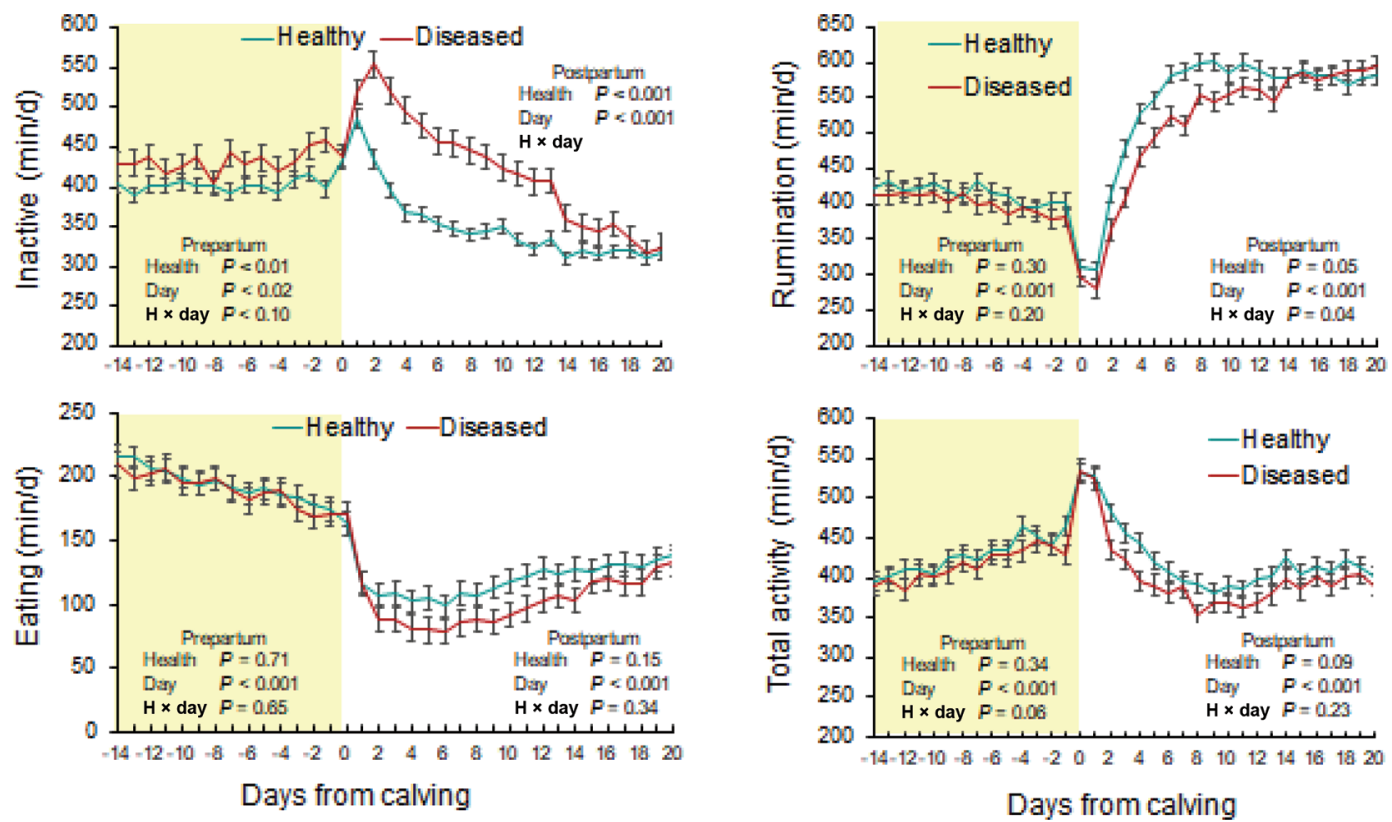

Figure 4. Least squares means $( \pm$ SEM) of inactive time (upper left panel), eating time (lower left panel), rumination time (upper right panel), and total activity (lower right panel) during $14 \mathrm{~d}$ before calving and $20 \mathrm{~d}$ postcalving for healthy $(\mathrm{n}=92)$ and diseased $(\mathrm{n}=68)$ dairy cows. Diseased cows included any case of defined metritis, digestive disorders, ketosis, hypocalcemia, calving problems, mastitis, or lameness during the first 60 DIM.

cows (502.5 \pm 9.3 vs. $551.3 \pm 9.5 \mathrm{~min} / \mathrm{d}$, respectively). Daily postpartum rumination was greater $(P<0.01)$ for cows calving during summer than winter-spring months $(558.2 \pm 10.1$ vs. $495.7 \pm 8.8 \mathrm{~min} / \mathrm{d}$, respectively). No interaction was detected for rumination time between health status and parity.

Eating times were not affected by health status during either period, but an acute decrease in prepartum eating time was evident during the last $24 \mathrm{~h}$ before calving, reaching nadirs on d 4 to 6 in healthy cows and diseased cows, but at a lower $(P<0.10)$ nadir in diseased cows. Thereafter, eating time increased slowly in all cows (Figure 4; lower left panel). Daily prepartum eating times were not affected by parity $(P=0.72)$ or season $(P=0.32)$. An interaction, however, was detected $(P=0.05)$ between health status and parity during the prepartum period, but not during the postpartum period. Healthy prepartum primiparous cows spent less $(P=0.04)$ time eating than healthy multiparous cows $(180.3 \pm 10.1$ vs. $209.1 \pm 10.3 \mathrm{~min} / \mathrm{d}$, respectively), whereas eating time did not differ $(P=$ $0.28)$ for diseased cows $(196.8 \pm 11.4$ vs. $184.4 \pm 11.5$ $\mathrm{min} / \mathrm{d}$, respectively). Furthermore, diseased multiparous cows tended $(P=0.11)$ to spend less time eating than healthy multiparous cows (184.4 \pm 11.5 vs. 209.1 $\pm 10.3 \mathrm{~min} / \mathrm{d}$, respectively). Postpartum eating time was greater $(P<0.01)$ for cows calving during winterspring than summer months $(131.4 \pm 7.0$ vs. $94.0 \pm 8.0$ $\min / \mathrm{d}$, respectively), but did not differ by parity $(P=$ $0.52)$.

Prepartum total daily activity was not affected by health status, but after calving, healthy cows tended $(P=0.09)$ to have greater activity than diseased cows (Figure 4; lower right panel). Both parity and season influenced prepartum total daily activity. Primiparous cows were more $(P<0.01)$ active than older cows $(446.6$ \pm 8.5 vs. $397.1 \pm 8.8 \mathrm{~min} / \mathrm{d}$, respectively), and summer total activity was greater $(P<0.01)$ than winter-spring daily activity $(457.7 \pm 9.4$ vs. $385.9 \pm 8.0 \mathrm{~min} / \mathrm{d}$, respectively). Postpartum total daily activity was greater $(P<0.01)$ in primiparous than multiparous cows $(443.3$ \pm 8.3 vs. $382.8 \pm 8.5 \mathrm{~min} / \mathrm{d}$, respectively) during both seasons. No interaction was detected for total activity between health status and parity.

\section{Ovarian Characteristics}

Median day to first ovulation was $33 \mathrm{~d}$. Mean days to first ovulation was $5.9 \mathrm{~d}$ less $(P=0.05)$ in healthy than diseased cows (Table 2), but was unaffected by parity $(P=0.14)$ or season $(P=0.47)$. More $(P=$ $0.05)$ healthy cows ovulated before the median $d 33$ and before AI $(P=0.05)$ compared with diseased cows. More primiparous than multiparous cows tended $(P=$ 0.09 ) to ovulate by d 33 (53.7 vs. $39.1 \%$, respectively), whereas more $(P=0.03)$ cows calving during winter- 
spring than during summer months ovulated by d 33 ( 55.6 vs. $37.3 \%$, respectively).

All healthy cows ovulated at least once before AI, whereas $92.5 \%$ of diseased cows ovulated more than once by AI (Table 2$)$. Primiparous cows had more $(P<$ 0.01 ) ovulations before AI than multiparous cows (2.1 \pm 0.09 vs. $1.7 \pm 0.9$, respectively) in both seasons. The odds for cows having delayed ovulation (not ovulating before median d 33 postpartum) were 1.92 times greater $(P=0.04)$ for diseased than healthy cows. Metritis, ketosis, and digestive disorders were the only diseases that each individually increased $(P<0.05)$ the odds of delayed first postpartum ovulation by $2.48,5.72$, and 2.65 times, respectively (Table 1 ).

Days to first estrus, duration of first estrus, and intensity of first estrus did not differ according to health status, but healthy cows tended $(P=0.09)$ to have more periods of estrus before AI than diseased cows (Table 2). Neither parity $(P>0.26)$ nor season of calving $(P>0.13)$ affected these estrual traits, except that the number of periods of estrus detected before AI was greater during summer than winter-spring months (1.2 \pm 0.1 vs. $0.7 \pm 0.1$, respectively).

More $(P=0.03)$ healthy cows had a corpus luteum present at GnRH-1 than diseased cows (Table 2). More summer-calving cows had a corpus luteum present at GnRH-1 than for cows calving during winter-spring months ( 88.0 vs. $69.2 \%$, respectively). Concentrations of serum progesterone before GnRH-1, $\mathrm{PGF}_{2 \alpha}$, and at AI did not differ $(P=0.27)$ by health status. Neither parity $(P=0.13)$ nor season $(P=0.36)$ affected concentrations of progesterone. Four cows failed to have luteolysis before AI (concentrations of progesterone $\leq 0.32 \mathrm{ng} / \mathrm{mL}$ ), with 2 cows in each health status category.

In contrast, no other ovarian traits (Table 2) assessed by transrectal ultrasonography differed by health status including diameter of follicles assessed before GnRH-1, $\mathrm{PGF}_{2 \alpha}$, and at $24 \mathrm{~h}$ before $\mathrm{AI}$, or average ovulation response to GnRH-1 (41.9\%) or GnRH-2 (89.7\%). Ovulation response after $\mathrm{GnRH}-1$ was greater $(P=0.02)$ for cows calving during summer than winter-spring months (51.8 vs. $32.3 \%$, respectively), but did not differ $(P=0.21)$ after GnRH-2 (86.4 vs. $92.6 \%$, respectively). Ovarian follicular diameters were consistently 1.0 to $1.1 \pm 0.4 \mathrm{~mm}$ greater $(P<0.05)$ in multiparous compared with primiparous cows at each time point. Moreover, for cows calving during summer compared with winter-spring months, follicles were 0.9 to $1.8 \pm$ $0.4 \mathrm{~mm}$ smaller $(P<0.05)$ in diameter.

\section{BCS, BW, and Milk Yield}

Body condition scores did not differ at calving but were greater $(P=0.04)$ for healthy than diseased cows at first AI (Table 3). Primiparous cows had greater $(P=0.04)$ BCS at the time of AI compared with multiparous cows $(2.5 \pm 0.04$ vs. $2.4 \pm 0.04)$. Weekly BCS tended $(P=0.07)$ to be greater throughout the prebreeding period for healthy cows compared with

Table 2. Estrus and ovarian characteristics of healthy and diseased dairy cows

\begin{tabular}{|c|c|c|c|}
\hline Item & Healthy & Disease $^{1}$ & $P$-value \\
\hline First ovulation by d $33^{2}(\%)$ & $54.7(92)^{3}$ & $38.2(68)$ & 0.05 \\
\hline Days to first ovulation $^{2}$ & $34.4 \pm 1.7(92)$ & $40.3 \pm 2.0(68)$ & 0.02 \\
\hline Number of ovulations before $\mathrm{AI}^{4}$ & $2.1 \pm 0.08(91)$ & $1.8 \pm 1.0(67)$ & 0.05 \\
\hline Ovulation before AI (\%) & $100(91)$ & $92.5(61)$ & $<0.01$ \\
\hline Days to first estrus & $43.3 \pm 2.4(61)$ & $46.1 \pm 3.0(38)$ & 0.46 \\
\hline Duration of estrus $(\mathrm{h})$ & $13.5 \pm 1.4(61)$ & $11.9 \pm 1.7(38)$ & 0.47 \\
\hline Intensity of first estrus (units) & $5.1 \pm 0.2(61)$ & $4.7 \pm 0.3(38)$ & 0.30 \\
\hline Number of estrual periods before AI & $1.1 \pm 0.1(61)$ & $0.8 \pm 0.1(38)$ & 0.09 \\
\hline Estrus before AI (\%) & $67.0(61)$ & $56.7(38)$ & 0.19 \\
\hline Estrus at $\mathrm{AI}(\%)$ & $24.2(61)$ & $26.9(38)$ & 0.67 \\
\hline \multicolumn{4}{|l|}{$\mathrm{GnRH}-1^{4}$} \\
\hline Follicle diameter (mm) & $12.9 \pm 0.4(90)$ & $12.8 \pm 0.4(67)$ & 0.76 \\
\hline Corpus luteum present (\%) & $86.4(90)$ & $72.1(67)$ & 0.03 \\
\hline Ovulation (\%) & $42.8(90)$ & $40.7(67)$ & 0.80 \\
\hline \multicolumn{4}{|l|}{$\mathrm{PGF}_{2 \alpha}-1$} \\
\hline Follicle diameter $(\mathrm{mm})$ & $12.0 \pm 0.3(90)$ & $12.4 \pm 0.4(67)$ & 0.36 \\
\hline \multicolumn{4}{|l|}{ GnRH-2 } \\
\hline Follicle diameter $(\mathrm{mm})$ & $13.6 \pm 0.3(90)$ & $13.8 \pm 0.4(67)$ & 0.72 \\
\hline Ovulation (\%) & $88.8(90)$ & $91.0(67)$ & 0.66 \\
\hline
\end{tabular}

\footnotetext{
${ }^{1}$ Any case of diagnosed metritis, digestive disorders, ketosis, hypocalcemia, calving problems, mastitis, or lameness during the first 60 DIM.

${ }^{2}$ First increase in weekly progesterone $\geq 1 \mathrm{ng} / \mathrm{mL}$ or ultrasound-detected corpus luteum by 33 DIM (median).

${ }^{3}$ Number of cows in parentheses.

${ }^{4}$ Two cows were anovulatory before ovulation synchronization starting at $63 \pm 3$ DIM; GnRH-1, PGF $2 \alpha$, and GnRH-2 were administered at 63, 70, and 72 DIM (see Figure 1).
} 
Table 3. Calving difficulty, body condition, BW, and milk yield of healthy and diseased dairy cows (LSM \pm SEM)

\begin{tabular}{lccc}
\hline Item & $\begin{array}{c}\text { Healthy } \\
(\mathrm{n}=92)\end{array}$ & $\begin{array}{c}\text { Disease }^{1} \\
(\mathrm{n}=68)\end{array}$ & $P$-value \\
\hline BCS at calving & & \\
BCS at first AI & $2.9 \pm 0.05$ & $2.8 \pm 0.06$ & 0.37 \\
Change in BCS & $2.5 \pm 0.04$ & $2.4 \pm 0.04$ & 0.03 \\
BW at calving (kg) & $-0.4 \pm 0.05$ & $-0.5 \pm 0.06$ & 0.56 \\
BW at first AI (kg) & $662 \pm 6.5$ & $670 \pm 7.6$ & 0.39 \\
Change in BW (kg) & $619 \pm 5.8$ & $622 \pm 6.8$ & 0.68 \\
Test-day (51 to 94 DIM) & $-43.3 \pm 3.6$ & $-48.1 \pm 4.2$ & 0.36 \\
Milk (kg/d) & $49.0 \pm 0.8$ & $49.1 \pm 0.9$ & 0.93 \\
Fat (kg/d) & $1.5 \pm 0.04$ & $1.6 \pm 0.04$ & 0.35 \\
Fat (\%) & $3.3 \pm 0.1$ & $3.4 \pm 0.1$ & 0.48 \\
Protein (kg/d) & $1.2 \pm 0.01$ & $1.2 \pm 0.01$ & 0.95 \\
Protein (\%) & $2.6 \pm 0.06$ & $2.7 \pm 0.07$ & 0.79 \\
3.5\% FCM (kg/d) & $47.1 \pm 0.9$ & $48.1 \pm 1.0$ & 0.43 \\
ECM (kg/d) & $46.2 \pm 0.8$ & $47.1 \pm 0.9$ & 0.48 \\
SCC (× 1,000) & $177 \pm 39$ & $127 \pm 46$ & 0.40 \\
Mean first 14-wk milk (kg/d) & $46.6 \pm 0.7$ & $44.5 \pm 0.8$ & 0.03 \\
150-d ECM (kg) & $44.2 \pm 0.8$ & $44.3 \pm 0.9$ & 0.94 \\
305-d ECM (kg) & $12,215 \pm 150$ & $11,931 \pm 176$ & 0.21 \\
\hline
\end{tabular}

\footnotetext{
${ }^{1}$ Any case of diagnosed metritis, digestive disorders, ketosis, hypocalcemia, calving problems, mastitis, or lameness during the first 60 DIM.

${ }^{2} 1=$ thin; $5=$ obese.
}

diseased cows (Figure 5; upper panel). Weekly BCS did not differ by parity $(P=0.43)$ or season of calving $(P$ $=0.59$ ). Body weight at calving and at first AI did not differ by health status (Table 3), but when weekly BW was expressed as a percentage of the first postcalving BW, healthy cows had greater percentage BW during wk 2 through 7 (health status by week interaction; $P=$ 0.03; Figure 5; lower panel) than diseased cows. Neither parity $(P=0.64)$ nor season of calving $(P=0.37)$ influenced percentage BW.

None of test-day milk characteristics assessed during a period $\pm 20 \mathrm{~d}$ of $\mathrm{AI}$ differed between health status groups (Table 3). Expected parity differences were observed for yields of fat, percentages of fat, and protein. Earlier ovulating cows produced more $(P<0.01)$ milk protein $(1.3 \pm 0.01$ vs. $1.2 \pm 0.01 \mathrm{~kg})$ and greater $(P$ $<0.01)$ milk protein percentages $(2.8 \pm 0.06$ vs. 2.5 $\pm 0.07)$ than later ovulating cows. Primiparous cows produced more $(P<0.01)$ fat $(1.7 \pm 0.04$ vs. $1.4 \pm$ $0.04 \mathrm{~kg})$, and greater $(P<0.01)$ percentage of milk fat $(4.2 \pm 0.1$ vs. $2.5 \pm 0.1)$ and percentage of milk protein $(3.1 \pm 0.06$ vs. $2.2 \pm 0.07)$ than multiparous cows, respectively. As expected, multiparous cows produced more $(P<0.01)$ test-day milk than primiparous cows $(57.5 \pm 0.9$ vs. $40.5 \pm 0.8 \mathrm{~kg})$. In addition, mean test-day milk, ECM, and 3.5\% FCM yields were greater $(P<0.01)$ for cows calving during winter-spring than summer months.

Although 150-d and 305-d ECM did not differ between health status groups, mean daily milk yield during the first 14 wk of lactation was greater $(P=0.03)$ in healthy than diseased cows (Table 3 ) and greater for cows calving during winter-spring than summer months $(48.1 \pm 0.6$ vs. $43.0 \pm 0.9 \mathrm{~kg})$, respectively. Cows that ovulated earlier than d 33 tended $(P=0.09)$ to produce more 305-d ECM milk than later ovulating cows $(12,279 \pm 170$ vs. $11,898 \pm 158 \mathrm{~kg}$, respectively). As expected, compared with primiparous cows, multiparous cows produced more $(P<0.01)$ average daily milk $(53.9 \pm 0.7$ vs. $37.2 \pm 0.7 \mathrm{~kg})$ during the first $14 \mathrm{wk}$ of lactation and more $(P<0.01) 305-\mathrm{d}$ ECM $(13,229 \pm$ 167 vs. $10,948 \pm 161 \mathrm{~kg}$ ), respectively.

\section{DISCUSSION}

The present study characterized ovarian activity, metabolic and production traits, and activity-recorded physical traits of postpartum diseased and healthy dairy cows. Our first objective was to characterize how disease affects various metabolic measures. All metabolic profiles assessed on d $0,3,7$, and 14 validated the health status of cows in the present study. Elevated FFA, BHB, calcium, and haptoglobin were consistent with cows diagnosed with periparturient disease. Concentrations of NEFA or FFA can serve as markers for negative energy balance (NEB), and are associated with incidence of clinical ketosis, and displaced abomasum (LeBlanc et al., 2005; Chapinal et al., 2011). Concentrations of BHB also are used as a marker for NEB and elevated concentrations of BHB associated with hyperketonemia have negative effects on milk production, early culling, and subsequent reproductive performance (Duffield et al., 2009). Hypocalcemia is associated with long-term effects of clinical diseases 
(Venjakob et al., 2018). Plasma calcium concentration measured within $12 \mathrm{~h}$ of parturition, however, was a poor predictor of early lactation health outcomes because reduced calcium concentration in the immediate postpartum period was associated with greater milk production in multiparous cows (Neves et al., 2018). Therefore, in the present study, 3 of 4 samples collected for calcium analyses $<2.2 \mathrm{mmol} / \mathrm{L}$ were the threshold for diagnosing hypocalcemia. During the transition period, metabolic changes affect immune function and increase susceptibility to postpartum diseases (Goff and Horst, 1997). Increased serum haptoglobin is observed in response to tissue damage, inflammation, infection, and bacterial components (Lomborg et al., 2008) and during $3 \mathrm{~d}$ before the onset of clinical signs of metritis (Huzzey et al., 2009).

Our second objective was to characterize how periparturient disease affects physical traits including first postpartum ovulation and estrus of transition dairy
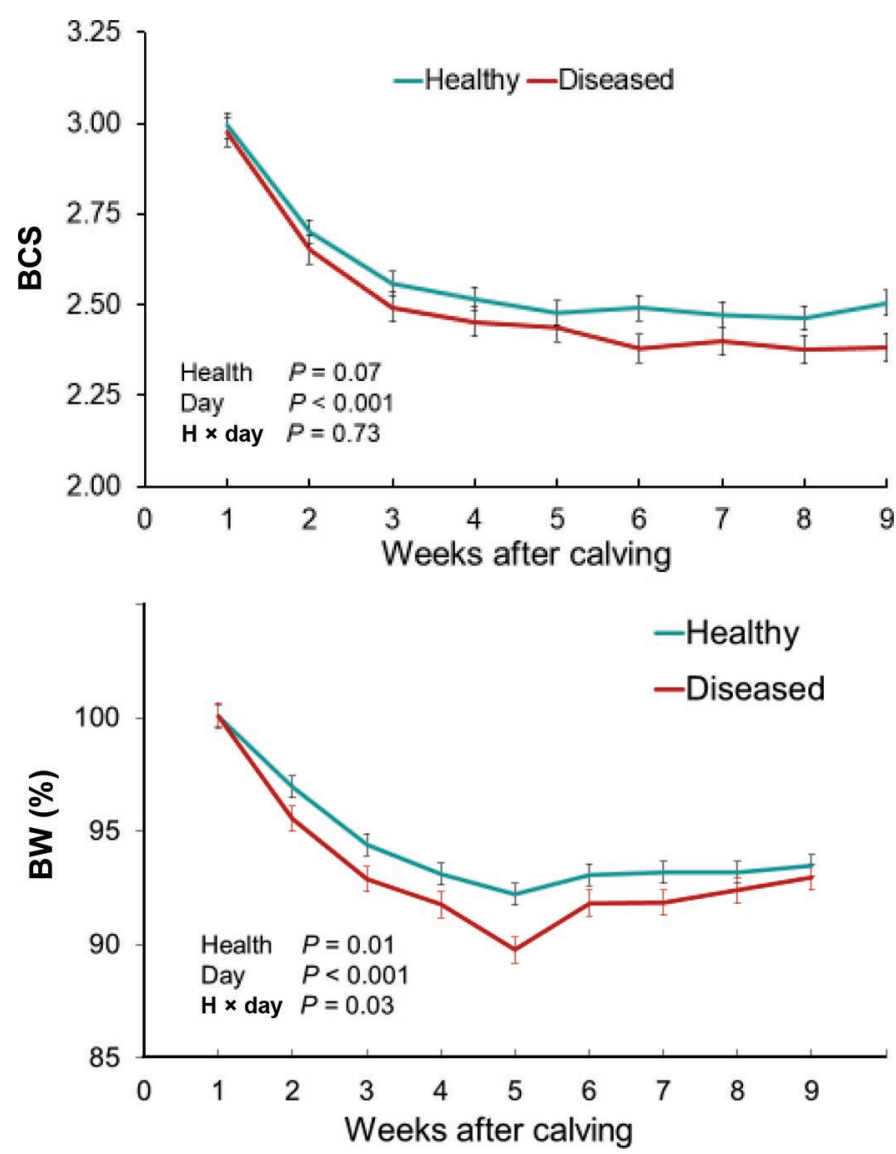

Figure 5. Least squares means ( \pm SEM) of BCS (upper panel) and percentage BW relative to the first postcalving BW (lower panel) during the first 9 wk after calving for healthy $(\mathrm{n}=92)$ and diseased $(\mathrm{n}=$ 68) dairy cows. Diseased cows included any case of defined metritis, digestive disorders, ketosis, hypocalcemia, calving problems, mastitis, or lameness during the first 60 DIM. cows. Resumption of ovulation after parturition is a coordinated process that involves recoupling of the growth hormone/IGF-1 axis in the liver, increase in follicular development and steroidogenesis, and removal of negative feedback from estradiol in the hypothalamus (Santos et al., 2016). Furthermore, infectious diseases and metabolic disorders associated with extensive NEB during early lactation disrupt this pathway and can delay first ovulation postpartum. Delayed resumption of ovulation is associated with dystocia, extensive NEB, and loss of body condition postpartum, as well as the occurrence of diseases during early lactation (Walsh et al., 2007; Ribeiro et al., 2013). Hormonal and metabolic environments imposed by such circumstances decrease the frequency of LH pulses (Schillo, 1992; Kadokawa et al., 2006). Moreover, the period after the NEB nadir when EB status is improving is related to a predictable onset of postpartum LH pulse frequency necessary to facilitate follicle maturation and first ovulation (Canfield and Butler, 1990).

Although only 2 cows had prolonged anovulation that persisted until the beginning of the ovulation synchronization period, more healthy than diseased cows ovulated early and before the postpartum median of 33 d. Consistent with an almost 6 -d average earlier ovulation in healthy cows was the increased frequency of ovulation and a tendency for more periods of estrus before first AI, and more healthy cows bearing a corpus luteum at GnRH-1. The likelihood is small, but with once weekly sampling for progesterone determinations, a short-term increase in progesterone may have gone undetected.

Almost all lactating dairy cows undergo a period of NEB, metabolic stress, and loss of BCS and BW because of inadequate energy intake and mobilization of body reserves to meet energy requirements for lactogenesis (Drackley, 1999; Rutherford et al., 2016). Loss in percentage change in BW and BCS was greater in cows diagnosed with disease in the present study, supporting the concept that postpartum health problems are associated with losses in BW, BCS, and extended anovulation (Santos et al., 2009, 2010; Gärtner et al., 2019). Furthermore, pregnancy per AI at 70 DIM differed by BCS change between calving and d 21 postpartum. Pregnancy per AI was least for cows that lost BCS $(22.8 \%)$, intermediate for cows that maintained BCS $(36.0 \%)$, and greatest for cows that gained BCS (78.3\%; Carvalho et al., 2014).

Activity monitoring is the most commonly tested automated estrus detection system used commercially (Stevenson, 2014). Measured performances that correlate with visual observations indicate activity monitors provide accurate information for use in management of dairy cows (Borchers et al., 2016). In the present study, 
clear differences were observed in activities of cows before and after calving, which were associated with their postpartum health status. Cows classified as healthy after calving in our study had less inactivity during 2 wk before and 3 wk after calving, and tended to have greater total daily activity after calving compared with diseased cows.

More recumbency and inactivity of diseased cows is consistent with their health status. Differences in the peak of inactivity for healthy and diseased cows were evident in our study and were similar in response to cows fitted with a different pastern-mounted activity monitor (Piñeiro et al., 2019). Multiparous lactating cows in the latter study, however, had increased lying time concomitant with increased postpartum health events, whereas primiparous cows spent more time standing during the transition period and showed a different behavioral response to sickness than multiparous cows (Piñeiro et al., 2019). Our observations are consistent with the latter in which multiparous cows diagnosed with disease after calving were more inactive before calving than their healthy counterparts, whereas these differences were not detected in future primiparous cows. Furthermore, prepartum NEFA had a positive quadratic association with prepartum lying time (Piñeiro et al., 2019).

Rumination duration decreased by $33 \%$ from the day before calving to d 0 and 1 (Clark et al., 2015), which is similar to the 22 to $25 \%$ decrease observed in the present study, but prepartum rumination time did not differ between cows with different health statuses. In contrast, rumination increased more quickly and peaked by d 6 to 9 compared with a later peak in diseased cows in our study. Observed postpartum rumination time is consistent with an earlier report of cows characterized by mild inflammatory conditions and without health disorders compared with cows with mild health disorders during the puerperium showing a greater average rumination time during the first 10 DIM (Soriani et al., 2012). Prepartum days relative to calving, stillbirth, subclinical hypocalcemia, and retained fetal membranes were associated with daily rumination time, whereas postpartum daily rumination time was associated with days relative to calving, twinning, subclinical hypocalcemia, subclinical ketosis, and retained fetal membranes (Liboreiro et al., 2015). These experiments and the present study show the potential to use rumination duration to predict the day of calving (Soriani et al., 2012; Pahl et al., 2014; Clark et al., 2015).

Subclinical hyperketonemia and uterine disease had a diminishing effect on rumen activity and BW but had no influence on milk yield (Gáspárdy et al., 2014). When complemented by the change of $\mathrm{BW}$ in the latter study, rumination time was a useful general indicator of health status and subclinical disease before the appearance of clinical signs. Monitoring rumination time and physical activity seemed to be useful for specifically identifying cows with metabolic and digestive disorders during the early postpartum period (Stangaferro et al., 2016a) and for identifying cows with clinical cases of mastitis caused by Escherichia coli and cases of mastitis concurrent with another health disorder (Stangaferro et al., 2016b). Furthermore, automated rumination and activity monitoring was effective for identifying cows with severe cases of metritis or cows with metritis and another health disorder, whereas the identification of cows with mild cases of metritis was less accurate (Stangaferro et al., 2016c). Finally, rumination time measured by automated activity monitors was positively associated with milk yield in early lactating dairy cows regardless of parity, whereas rumination time was negatively associated with milk fat composition and milk fat to protein ratios in multiparous cows (Kaufman et al., 2018).

Although visually observed feeding behavior and activity-monitored eating time are moderately correlated when using the SensOor ear tags (Borchers et al., 2016), eating times were underestimated by these same ear tag sensors used in the present study compared with previous visual observations (Grant and Albright, 2000). Our observations are consistent with conclusions of another report (Zambelis et al., 2019) in which the same sensors showed promise for identifying feeding behaviors in general, but the independent classification of rumination and eating may require additional sensitivity. Despite seemingly underestimating the absolute magnitude of eating time, healthy cows in our study tended to spend more time eating than diseased cows during the postpartum period. Although eating and rumination times did not differ by health status before calving, healthy cows ruminated more and tended to spend more time eating than diseased cows. A recent review concluded that monitoring chewing activity of dairy cows by low-cost sensors in commercial facilities can provide information that is helpful in management decisions, especially when combined with other criteria despite their somewhat variable accuracy and precision (Beauchemin, 2018). Relative differences in activity measures between healthy and diseased cows may be useful, even though absolute daily eating or rumination times may not be assessed accurately.

\section{CONCLUSIONS}

Disease status was associated with greater serum concentrations of FFA, BHB, and haptoglobin, greater rectal temperature, and lesser calcium on postpartum d 
$0,3,7$, and 14 . Rectal temperatures were greater on d 3, 7, and 14 in diseased cows, whereas plasma glucose was not affected by disease status. Prebreeding weekly assessments of BCS tended to be greater whereas percentage BW was greater in healthy than diseased cows. Disease delayed first postpartum ovulation. Activity measures differed by health status during prepartum and postpartum periods except for eating time. Healthy cows were more active during both periods compared with diseased cows and had greater postpartum rumination times. Acute changes in all activities were associated with calving and could serve as predictors of impending parturition based on abrupt decreases in rumination and acute increases in total activity.

\section{ACKNOWLEDGMENTS}

We thank our dairy team at the Kansas State University Teaching and Research Center for care of the experimental cows including daily feeding, milking, and health care. We acknowledge Theresa Rathburn, Dayanna Valerio, and Laman Mamedova (Kansas State University) for their laboratory assistance in conducting the metabolic assays. The authors have not stated any conflicts of interest.

\section{REFERENCES}

Barragan, A. A., J. Lakritz, M. K. Carman, S. Bas, E. Hovingh, and G. M. Schuenemann. 2019. Short communication: Assessment of biomarkers of inflammation in the vaginal discharge of postpartum dairy cows diagnosed with clinical metritis. J. Dairy Sci. 102:7469 7475. https://doi.org/10.3168/jds.2018-15854.

Beauchemin, K. A. 2018. Invited review: Current perspectives on eating and rumination activity in dairy cows. J. Dairy Sci. 101:47624784. https://doi.org/10.3168/jds.2017-13706.

Bicalho, M. L., E. C. Marques, R. O. Gilbert, and R. C. Bicalho. 2017. The association of plasma glucose, BHBA, and NEFA with postpartum uterine diseases, fertility, and milk production of Holstein dairy cows. Theriogenology 88:270-282. https://doi.org/10.1016/j .theriogenology.2016.09.036.

Borchers, M. R., Y. M. Chang, I. C. Tsai, B. A. Wadsworth, and J. M. Bewley. 2016. A validation of technologies monitoring dairy cow feeding, ruminating, and lying behaviors. J. Dairy Sci. 99:74587466. https://doi.org/10.3168/jds.2015-10843.

Canfield, R. W., and W. R. Butler. 1990. Energy balance and pulsatile LH secretion in early postpartum dairy cattle. Domest. Anim. Endocrinol. 7:323-330. https://doi.org/10.1016/0739-7240(90)90038 $-2$.

Carvalho, M. R., F. Peñagaricano, J. E. P. Santos, T. J. DeVries, B. W. McBride, and E. S. Ribeiro. 2019. Long-term effects of postpartum clinical disease on milk production, reproduction, and culling of dairy cows. J. Dairy Sci. 102:11701-11717. https://doi .org/10.3168/jds.2019-17025.

Carvalho, P. D., A. H. Souza, M. C. Amundson, K. S. Hackbart, M. J. Fuenzalida, M. M. Herlihy, H. Ayres, A. R. Dresch, L. M. Vieira, J. N. Guenther, R. R. Grummer, P. M. Fricke, R. D. Shaver, and M. C. Wiltbank. 2014. Relationships between fertility and postpartum changes in body condition and body weight in lactating dairy cows. J. Dairy Sci. 97:3666-3683. https://doi.org/10.3168/ jds.2013-7809.
Chapinal, N., M. Carson, T. F. Duffield, M. Capel, S. Godden, M. Overton, J. E. Santos, and S. J. LeBlanc. 2011. The association of serum metabolites with clinical disease during the transition period. J. Dairy Sci. 94:4897-4903. https://doi.org/10.3168/jds $.2010-4075$.

Clark, C. E., N. A. Lyons, L. Millapan, S. Talukder, G. M. Cronin, K. L. Kerrisk, and S. C. Garcia. 2015. Rumination and activity levels as predictors of calving for dairy cows. Animal 9:691-695. https:/ /doi.org/10.1017/S1751731114003127.

Drackley, J. K. 1999. Biology of dairy cows during the transition period: The final frontier? J. Dairy Sci. 82:2259-2273. https://doi .org/10.3168/jds.S0022-0302(99)75474-3.

Dubuc, J., and S. Buczinski. 2018. Short communication: Cow- and herd-level prevalence of hypoglycemia in hyperketonemic postpartum dairy cows. J. Dairy Sci. 101:3374-3379. https://doi.org/10 .3168/jds.2017-13773.

Duffield, T. F., K. D. Lissemore, B. W. McBride, and K. E. Leslie. 2009. Impact of hyperketonemia in early lactation dairy cows on health and production. J. Dairy Sci. 92:571-580. https://doi.org/ $10.3168 /$ jds.2008-1507.

Edmonson, A. J., I. J. Lean, L. D. Weaver, T. Farver, and G. Webster. 1989. A body condition scoring chart for Holstein dairy cows. J. Dairy Sci. 72:68-78. https://doi.org/10.3168/jds.S0022 -0302(89)79081-0.

Gärtner, T., E. Gernand, J. Gottschalk, and K. Donat. 2019. Relationships between body condition, body condition loss, and serum metabolites during the transition period in primiparous and multiparous cows. J. Dairy Sci. 102:9187-9199. https://doi.org/10 $.3168 /$ jds.2018-15762.

Gáspárdy, A., G. Efrat, A. C. Bajcsy, and S. G. Fekete. 2014. Electronic monitoring of rumination activity as an indicator of health status and production traits in high-yielding dairy cows. Acta Vet. Hung. 62:452-462. https://doi.org/10.1556/avet.2014.026.

Goff, J. P., and R. L. Horst. 1997. Physiological changes at parturition and their relationship to metabolic disorders. J. Dairy Sci. 80:1260-1268. https://doi.org/10.3168/jds.S0022-0302(97)76055 $-7$.

Grant, R. J., and J. L. Albright. 2000. Feeding behaviour. Page 365382 in Farm Animal Metabolism and Nutrition. J. P. F. D. Mello, ed. CABI Publishing, Wallingford, Oxon, UK.

Habeeb, A. A., A. E. Gad, and M. A. Atta. 2018. Temperature-humidity indices as indicators to heat stress of climatic conditions with relation to production and reproduction of farm animals. Int. J. Biotechnol. Rec. Adv. 1:35-50. https://doi.org/10.18689/ijbr $-1000107$.

Hill, S. L., D. M. Grieger, K. C. Olson, J. R. Jaeger, C. R. Dahlen, M. R. Crosswhite, N. Negrin Pereira, S. R. Underdahl, B. W. Neville, J. Ahola, M. C. Fischer, G. E. Seidel, and J. S. Stevenson. 2016. Gonadotropin-releasing hormone increased pregnancy risk in suckled beef cows not detected in estrus and subjected to a split-time artificial insemination program. J. Anim. Sci. 94:3722-3728. https: //doi.org/10.2527/jas.2016-0582.

Huzzey, J. M., T. F. Duffield, S. J. LeBlanc, D. M. Veira, D. M. Weary, and M. A. G. von Keyserlingk. 2009. Short communication: Haptoglobin as an early indicator of metritis. J. Dairy Sci. 92:621-625. https://doi.org/10.3168/jds.2008-1526.

Kadokawa, H., D. Blache, and G. B. Martin. 2006. Plasma leptin concentrations correlate with luteinizing hormone secretion in early postpartum Holstein cows. J. Dairy Sci. 89:3020-3027. https://doi .org/10.3168/jds.S0022-0302(06)72575-9.

Kaufman, E. I., V. H. Asselstine, S. J. LeBlanc, T. F. Duffield, and T. J. DeVries. 2018. Association of rumination time and health status with milk yield and composition in early-lactation dairy cows. J. Dairy Sci. 101:462-471. https://doi.org/10.3168/jds.2017-12909.

LeBlanc, S. J. 2010. Monitoring metabolic health in dairy cattle in the transition period. J. Reprod. Dev. 56(S):S29-S35. https://doi.org/ 10.1262/jrd.1056S29.

LeBlanc, S. J., K. E. Leslie, and T. F. Duffield. 2005. Metabolic predictors of displaced abomasum in dairy cattle. J. Dairy Sci. 88:159-170. https://doi.org/10.3168/jds.S0022-0302(05)72674-6. 
Liboreiro, D. N., K. S. Machado, P. R. B. Silva, M. M. Maturana, T. K. Nishimura, A. P. Brandão, M. I. Endres, and R. C. Chebel. 2015. Characterization of peripartum rumination and activity of cows diagnosed with metabolic and uterine diseases. J. Dairy Sci. 98:6812-6827. https://doi.org/10.3168/jds.2014-8947.

Lomborg, S. R., L. R. Nielsen, P. M. Heegaard, and S. Jacobsen. 2008. Acute phase proteins in cattle after exposure to complex stress. Vet. Res. Commun. 32:575-582. https://doi.org/10.1007/s11259 $-008-9057-7$.

Makimura, S., and N. Suzuki. 1982. Quantitative determination of bovine serum haptoglobin and its elevation in some inflammatory diseases. Jpn. J. Vet. Sci. 44:15-21. https://doi.org/10.1292/ jvms1939.44.15.

Martinez, N., L. D. P. Sinedino, R. S. Bisinotto, R. Daetz, C. Lopera, C. A. Risco, K. N. Galvão, W. W. Thatcher, and J. E. P. Santos. 2016. Effects of oral calcium supplementation on mineral and acidbase status, energy metabolites, and health of postpartum dairy cows. J. Dairy Sci. 99:8397-8416. https://doi.org/10.3168/jds.2015 $-10527$.

Mohtashamipour, F., E. Dirandeh, Z. Ansari-Pirsaraei, and M. G. Colazo. 2020. Postpartum health disorders in lactating dairy cows and its associations with reproductive responses and pregnancy status after first timed-AI. Theriogenology 141:98-104. https://doi .org/10.1016/j.theriogenology.2019.09.017.

NAHMS (National Animal Health Management Service). 2014. Dairy 2014 Health and Management Practices on U.S. Dairy Operations. Accessed Mar. 2, 2020. https://www.aphis.usda.gov/animal _health/nahms/dairy/downloads/dairy14/Dairy14_dr_PartIII .pdf.

Neves, R. C., B. M. Leno, M. D. Curler, M. J. Thomas, T. R. Overton, and J. A. A. McArt. 2018. Association of immediate postpartum plasma calcium concentration with early-lactation clinical diseases, culling, reproduction, and milk production in Holstein cows. J. Dairy Sci. 101:547-555. https://doi.org/10.3168/jds.2017-13313.

NOAA (National Oceanic and Atmospheric Administration). 1976. Livestock hot weather stress. Pages 31-37. US Dept. Commerce, Natl. Weather Serv. Central Reg., Reg. Operations Manual Lett. NOAA, Washington, DC.

Ospina, P. A., D. V. Nydam, T. Stokol, and T. R. Overton. 2010. Associations of elevated nonesterified fatty acids and beta-hydroxybutyrate concentrations with early lactation reproductive performance and milk production in transition dairy cattle in the northeastern United States. J. Dairy Sci. 93:1596-1603. https:// doi.org/10.3168/jds.2009-2852.

Pahl, C., E. Hartung, A. Grothmann, K. Mahlkow-Nerge, and A. Haeussermann. 2014. Rumination activity of dairy cows in the 24 hours before and after calving. J. Dairy Sci. 97:6935-6941. https:/ /doi.org/10.3168/jds.2014-8194.

Pinedo, P. J., and A. De Vries. 2010. Effect of days to conception in the previous lactation on the risk of death and live culling around calving. J. Dairy Sci. 93:968-977. https://doi.org/10.3168/jds $.2009-2408$

Piñeiro, J. M., B. T. Menichetti, A. A. Barragan, A. E. Relling, W. P. Weiss, S. Bas, and G. M. Schuenemann. 2019. Associations of pre- and postpartum lying time with metabolic, inflammation, and health status of lactating dairy cows. J. Dairy Sci. 102:3348-3361. https://doi.org/10.3168/jds.2018-15386.

Ribeiro, E. S., and M. R. Carvalho. 2017. Impact and mechanisms of inflammatory diseases on embryonic development and fertility in cattle. Anim. Reprod. 14:589-600. https://doi.org/10.21451/1984 -3143-AR1002.

Ribeiro, E. S., F. S. Lima, L. F. Greco, R. S. Bisinotto, A. P. A. Monteiro, M. Favoreto, H. Ayres, R. S. Marsola, N. Martinez, W. W. Thatcher, and J. E. P. Santos. 2013. Prevalence of periparturient diseases and effects on fertility of seasonally calving grazing dairy cows supplemented with concentrates. J. Dairy Sci. 96:5682-5697. https://doi.org/10.3168/jds.2012-6335.
Rutherford, A. J., G. Oikonomou, and R. F. Smith. 2016. The effect of subclinical ketosis on activity at estrus and reproductive performance in dairy cattle. J. Dairy Sci. 99:4808-4815. https://doi.org/ 10.3168/jds.2015-10154.

Santos, J. E. P., R. S. Bisinotto, and E. S. Ribeiro. 2016. Mechanisms underlying reduced fertility in anovular dairy cows. Theriogenology 86:254-262. https://doi.org/10.1016/j.theriogenology.2016.04 .038 .

Santos, J. E. P., R. S. Bisinotto, E. S. Ribeiro, F. S. Lima, L. F. Greco, C. R. Staples, and W. W. Thatcher. 2010. Applying nutrition and physiology to improve reproduction in dairy cattle. Soc. Reprod. Fertil. Suppl. 67:387-403.

Santos, J. E. P., H. M. Rutigliano, and M. F. Sá Filho. 2009. Risk factors for resumption of postpartum estrous cycles and embryonic survival in lactating dairy cows. Anim. Reprod. Sci. 110:207-221. https://doi.org/10.1016/j.anireprosci.2008.01.014.

Schillo, K. K. 1992. Effects of dietary energy on control of luteinizing hormone secretion in cattle and sheep. J. Anim. Sci. 70:1271-1282. https://doi.org/10.2527/1992.7041271x.

Soriani, N., E. Trevisi, and L. Calamari. 2012. Relationships between rumination time, metabolic conditions, and health status in dairy cows during the transition period. J. Anim. Sci. 90:4544-4554. https://doi.org/10.2527/jas.2011-5064.

Stangaferro, M. L., R. Wijma, L. S. Caixeta, M. A. Al-Abri, and J. O. Giordano. 2016a. Use of rumination and activity monitoring for the identification of dairy cows with health disorders. Part I. Metabolic and digestive disorders. J. Dairy Sci. 99:7395-7410. https:// doi.org/10.3168/jds.2016-10907.

Stangaferro, M. L., R. Wijma, L. S. Caixeta, M. A. Al-Abri, and J. O. Giordano. 2016b. Use of rumination and activity monitoring for the identification of dairy cows with health disorders. Part II. Mastitis. J. Dairy Sci. 99:7411-7421. https://doi.org/10.3168/jds .2016-10908.

Stangaferro, M. L., R. Wijma, L. S. Caixeta, M. A. Al-Abri, and J. O. Giordano. 2016c. Use of rumination and activity monitoring for the identification of dairy cows with health disorders. Part III. Metritis. J. Dairy Sci. 99:7422-7433. https://doi.org/10.3168/jds .2016-11352.

Stevenson, J. S. 2014. Impact of reproductive technologies on dairy food production in the dairy industry. Adv. Exp. Med. Biol 752:115-129. https://doi.org/10.1007/978-1-4614-8887-3_6.

Stevenson, J. S., and E. P. Call. 1988. Reproductive disorders in the periparturient dairy cow. J. Dairy Sci. 71:2572-2583. https://doi .org/10.3168/jds.S0022-0302(88)79846-X.

Venjakob, P. L., L. Pieper, W. Heuwieser, and S. Borchardt. 2018. Association of postpartum hypocalcemia with early-lactation milk yield, reproductive performance, and culling in dairy cows. J. Dairy Sci. 101:9396-9405. https://doi.org/10.3168/jds.2017-14202.

Walsh, R. B., D. F. Kelton, T. F. Duffield, K. E. Leslie, J. S. Walton, and S. J. LeBlanc. 2007. Prevalence and risk factors for postpartum anovulatory condition in dairy cows. J. Dairy Sci. 90:315-324. https://doi.org/10.3168/jds.S0022-0302(07)72632-2.

Weary, D. M., J. M. Huzzey, and M. A. von Keyserlingk. 2009. Using behavior to predict and identify ill health in animals. J. Anim. Sci. 87:770-777. https://doi.org/10.2527/jas.2008-1297.

Zambelis, A., T. Wolfe, and E. Vasseur. 2019. Validation of an ear-tag accelerometer to identify feeding and activity behaviors of tiestallhoused dairy cattle. J. Dairy Sci. 102:4536-4540. https://doi.org/ $10.3168 /$ jds.2018-15766.

\section{ORCIDS}

Jeffrey S. Stevenson @ (ittps://orcid.org/0000-0002-1770-8051 Luís G. D. Mendonça ๑ https://orcid.org/0000-0001-5717-7059 